\title{
Customer Satisfaction towards Honda Two Wheelers: A Case Study in Tirupati
}

\author{
${ }^{1}$ Dr. Duggani Yuvaraju(PDF-Scholar) \& ${ }^{2}$ Prof. S. Durga Rao \\ ${ }^{1,2}$ Department of Management Studies,S.V.University, Tirupati-517502.Andhra Pradesh
}

\begin{abstract}
Customer satisfaction is a feeling of pleasure or disappointment resulting from comparing a products perceived performance or outcome in relation to his or her expectations. In this paper we found that 60\% of respondents to know the advertisement of Honda Bike through media, 90 percent of the respondents were completely satisfied with the mileage and performance of the bike, $73 \%$ of respondents are satisfied with pick-up of the Honda Bike, 56\% of the respondents are attract the quality of the service to choose this bike, 50\% of the respondents are satisfied with the design of the bike, 54\% of the respondents considered the price of the Honda, $60 \%$ of the respondents felt the explanation to be "excellent". According to the chi-square test find that there is significance difference between the preferable factors like mileage, pickup, price and design.
\end{abstract}

\section{Introduction}

The two wheeler industry has been going steadily over the years all over the world. India is not an exception for that. Today India is the second largest manufactures of two wheelers in the world. It stands next only to Japan and China in terms of number of two wheelers produced and sold. Until 1990 geared scooters dominated the two wheelers market so much so that their sales equalled the combined sales of Motor cycles and Mopeds. Today the customer preferences have shifted from geared scooters to motorcycles and also to an extent to the premium end scooters. With rising fuel cost and more recently stringent emission norms imposed by the government, there is a distinct consumer preference for high efficiency. The Honda story is the story of one man, Soichiro Honda, and his unparalleled achievement of bringing motor cycles to the masses. Soichiro Honda was a racer, a businessman, and a manufacturer. But most of all he was a dreamer. He dreamed of a better way of making piston rings, founded a small company, and began production. He dreamed of giving people everywhere an economical form of transportation, and began producing small motorcycles, including one built in 1949 called the D-Type Dream. He also loved racing too. So his company built bigger and faster machines, two, four, five and six-cylinder race bikes and won the Isle of Man. Honda Motor Company is by far the world's biggest motorcycle maker. Honda's first motorcycle was born out of necessity in immediate post World War II Japan, where public transportation was desperately overcrowded and gasoline severely restricted. Unique practices create unique organizations.

Honda was established upon the fundamental belief in the value of each individual. Based on our philosophy, we respect independent spirit and freedom, equality and mutual trust of human beings who work for or come in contact with our company. As such our management policies focus on developing and enhancing the essential characteristics that every individual possesses - capacity to think, reason, and most importantly - the ability to dream. Being the largest producer of 2-wheelers and one of the most admired companies in the world definitely thrills us. But what thrills our associates most is the 'Joy of Creating', one of our missions at Honda, which promotes working for our own happiness. If you have a passion for 2 -wheelers and possess a challenging spirit, your abilities are more important to us rather than which university you passed from.

India will be the biggest global market for Honda's two-wheeler business by 2015 before eventually accounting for 30 per cent of its overall market share. At present, this is 13 per cent but the company is going flat out with new product launches as part of an aggressive growth strategy. The 110cc Dream Yuga motorcycle, unveiled at the Auto Expo here on Thursday, will roll out this year for the mass market, a segment in which Honda's former partner, the Hero group, rules the roost with the Splendour and Passion brands.

\section{Mass market pricing}

The Yuga is expected to be priced competitively at around Rs 45,000 , which could give the company the much needed momentum in its motorcycle business. The other launches included a new 110cc Dio scooter as well as the larger CBR150R and 250R bikes. Officials said Honda R\&D would now work closely with the Manesar operations of HMSI (Honda Motorcycle \& Scooter India), which would facilitate faster product launches in the coming years. In addition, the company will increase the number of its zonal offices and training centres keeping in mind the growing demand from smaller towns and the need to be closer to this critical buyer base. Clearly, Honda is determined to make up the lost numbers ceded to the Hero group, which works out to 
over five million units annually. The revised strategy will call for an aggressive play in the pricing segment while offering top quality products.

\section{Global share}

India will, in the process, take over from Indonesia and Vietnam as Honda's biggest two-wheeler market over the next five years. As for the bigger goal of 30 per cent share in its global business, Honda's annual two-wheeler volumes here would have to be in the region of 10 million units annually. Observers believe this could become a reality by 2020. At present, over four million units are in place from its three units in Manesar (the largest with 1.6 million), the recently commissioned Rajasthan plant and the newly identified site in Karnataka (with capacities of 1.2 million units each). The balance six million bikes and scooters, in that case, will have to be generated from new facilities even as reports are already doing the rounds that Honda is looking at options in the western and southern regions post-2014.

\section{Review of literature}

Dr.N.Chandrasekaran investigated the wants of the customer are carefully studied by conducting surveys on consumer behavior. The study also helps to know various marketing variables such as price and product features. This study will help gain knowledge about the influence of consumer to prefer a particular brand and the problems faced by them using such brands.

Dr.S.K.Sinha\&Ajay Wagh examined that India is one of the fastest growing telecommunication markets of the twenty first century. The common man, artisans, agricultural labours, vendors and workers from every walk of life are comfortably using the services provided by telecom industries. The potential of capturing market segment will surely depend upon understanding dynamics of customer's preference.

According to Lewis \&Boom service quality is considered as a measure of how well the service delivered matches customers expectations on providing a better service than the customer expect organizational brand promotional strategies should be based on developing innovative offers \& products, developing cost friendly value driven packages and tariffs, offering quality services after sales service $\&$ ability to make calls without getting cut off \&also to provide cheaper cost of calls to other networks.

Dr. C. Annandan\&M.Prasanna Mohan Raj \&Mr.S.Madhu examined the new mantra of all FMCG giants is; To get rich, sell to the rural,. So they have started marketing programs to explore the untapped segment of rural markets. As far as FMCG is concerned, the market penetration and consumption in rural areas is low so there is an opportunity for marketers to utilize the market effectively. Another key positive aspect is the current government focuses on rural areas. Understanding the rural customers.Inadequate data on rural markets.Reaching of products or services to 6.4 lakhs villages for poor infrastructure facility.

Rachel Dardis, HoracioSoberon-Ferrer investigated the consumer decision making is multinational, that is consumer choices are not base on a single product attributes, instead consumers view products as bundles of attributes. Product attributes (automobile attributes) as well as household characteristics. In both instances, the higher the value of the cost index or the Trouble Index, the more unsatisfactory the car is relative to other cars. A better educated household might be more informed about the performance properties of Japanese cars and attracted by the higher value reliability of these cars.

\section{Need For The Study}

Customer satisfaction provides an indication of how successful the organization is providing products and/or services to the market place. Organizations need to retain existing customers while targeting noncustomers. So, to retain the customers for longer time the marketer has to know the customer satisfaction levels. Thus, this study is conducted to know the satisfaction levels of customers of Hondabikes

\section{Scope Of The Study:}

The scope is confirmed only to examine the "Customer Satisfaction "with reference to Honda bikes" and to find possible remedies to counteract their competition.

\section{Objectives Of The Study}

- To find out the customers satisfaction level towards Honda bikesservices?

- To find out the factors that influence on customers, when they are purchasing Honda bikes.

\section{Limitations}

The survey was restricted to Tirupathi only.They may be few opinions, which might have been missed out.The accuracy of the analysis and conclusion drawn entirely depends upon the reliability of the information provided by the employees.Sincere efforts were made to cover maximum departments of the employees, but the 
study may not fully reflect the entire opinion of the employees.In the fast moving/changing employees behaviour, name new and better things may emerge in the near future, which cannot be safeguard in this report.

\section{Methodology}

A research design is considered as the framework or plan for a study thatguides as well as helps the data collection and analysis of data. Present study is an analytical and descriptive in nature and based on empirical study. The data was collected from both primary and secondary sources. The primary source of data is respondents concerned and collected by using a predefined questionnaire.The secondary sources include books, articles, periodicals, newspapers, various reports, websites etc.

\section{- Data Sources:}

The study is based on both primary and secondary data.

- Secondary Data:Secondary data is collected from the company records publications of Journals, Newspapers and Websites and websites.

Primary Data:Primary data is collected from the customers of Honda motors through Questionnaire.

- Research approach: Survey method

- Research instrument:

- Contact method:

- Data analysis:

Questionnaire

- Sampling Plan:

- Sampling unit:

Personal contact

Chi-square test, percentage analysis

- Sample size:

Customers of Honda bikes.

- Sampling method:

100

Convenience sampling method

\section{Data Analysis And Interpretation}

The data after collection have to be processed and analyzed in accordance with the outline laid down for the purpose at the time of developing the research plan. The processing of data implies editing, coding, classification, tabulation and presentation of collected data so that they are enable to data analysis.

1) Which brand do you own?

\begin{tabular}{|c|c|c|c|}
\hline S NO & PRODUCT & RESPONDENTS & $\%$ \\
\hline 1 & HERO & 60 & 60 \\
\hline 2 & HONDA & 20 & 20 \\
\hline 3 & TVS & 15 & 15 \\
\hline 4 & SUZUKI & 5 & 5 \\
\hline
\end{tabular}

CHART

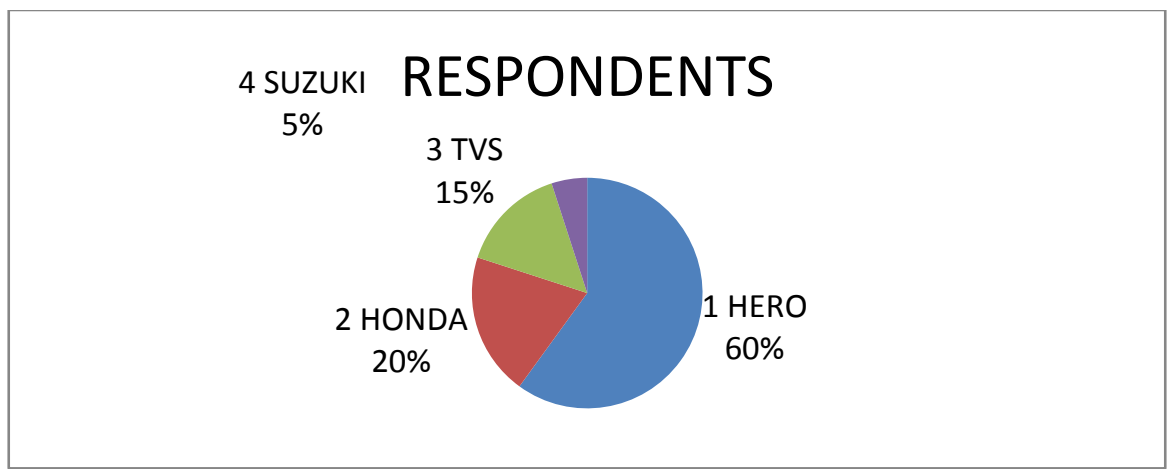

Interpretation: From above it can be stated that the general satisfaction level of for Honda in twin cities of Hyderabad and Secunderabad is $60 \%$.

2). Sources of awareness: The customer was enquired about the sources of awareness with regard the Honda. This will help to know us to which sources is playing a major role in creating awareness among the customers. 


\begin{tabular}{|l|c|c|c|}
\hline 1 & T.V & 35 & 35 \\
\hline 2 & NEWSPAPERS & 25 & 25 \\
\hline 3 & FRIENDS & 12 & 12 \\
\hline 4 & DEALERS & 28 & 28 \\
\hline
\end{tabular}

CHART

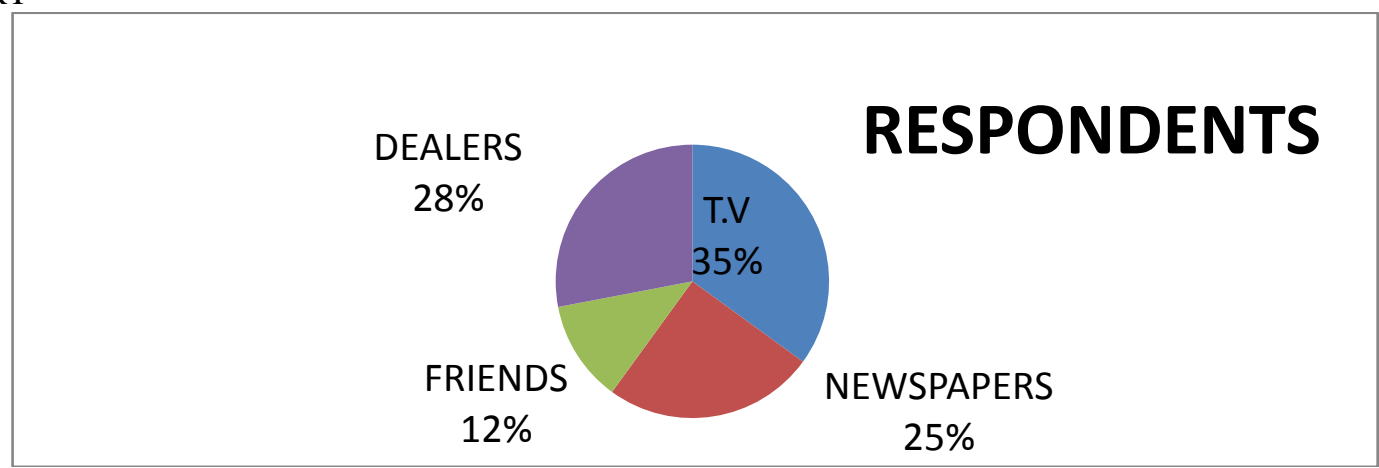

\begin{tabular}{|l|l|l|l|}
\hline & & & \\
\hline 1 & EXCELLENT & 30 & 30 \\
\hline 2 & GOOD & 20 & 20 \\
\hline 3 & AVERAGE & 40 & 40 \\
\hline 4 & POOR & 10 & 10 \\
\hline
\end{tabular}

Interpretation:Out of the responses obtained from 100 customers $28 \%$ said that they became aware of the Friends. And through the friends $35 \%$ of the customers are aware from the T.V.And another $25 \%$ are aware of by the NEWS PAPERS. And only $12 \%$ are aware by the DEALERS.

\section{3). Level of satisfaction on design}

The customer was enquired about the level of satisfaction with regard to the Honda.

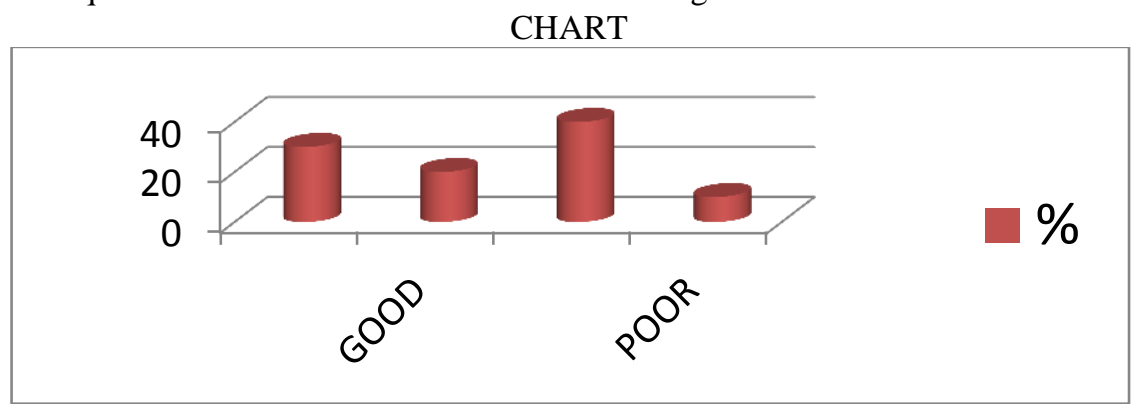

Interpretation:Out of the responses obtained from 100 customers $30 \%$ said that they are excellent satisfied and $20 \%$ were good and $40 \%$ were average and $10 \%$ were vehicle is poor. This data is obtained by most of members were satisfied by hero product.

4). What are the valuable attributes you normally look while purchasing a Two-wheeler?

\begin{tabular}{|c|c|c|c|}
\hline S NO & ATTRIBUTES & RESPONDENTS & $\%$ \\
\hline 1 & QUALITY SERVICE & 56 & 56 \\
\hline 2 & LESS PRICE & 20 & 20 \\
\hline 3 & BRAND IMAGE & 24 & 24 \\
\hline 4 & TOTAL & 100 & 100 \\
\hline
\end{tabular}




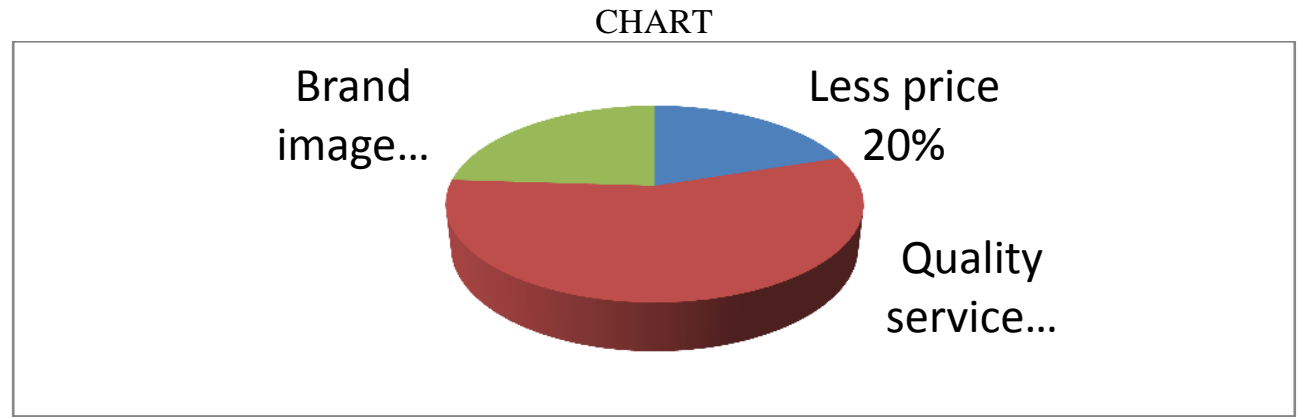

Interpretation:From the above it can be stated that general normally any one while purchasing a four wheeler most of the members are seeing 50\% of members are seeing PERFORMENS and 30\% of members are seeing DESIGN And 10\% of members are seeing PRICE and 10\% of members are Others.

5. Suggesting to friends: The following table is regarding the customer likeliness in suggesting this showroom to other friends. This is an indicator of customer satisfaction also.

Let's see the responses.

\begin{tabular}{|c|c|c|c|}
\hline S NO & SUGGEST FRIENDS & RESPONDENTS & $\%$ \\
\hline 1 & YES & 90 & 90 \\
\hline 2 & NO & 10 & 10 \\
\hline
\end{tabular}

CHART

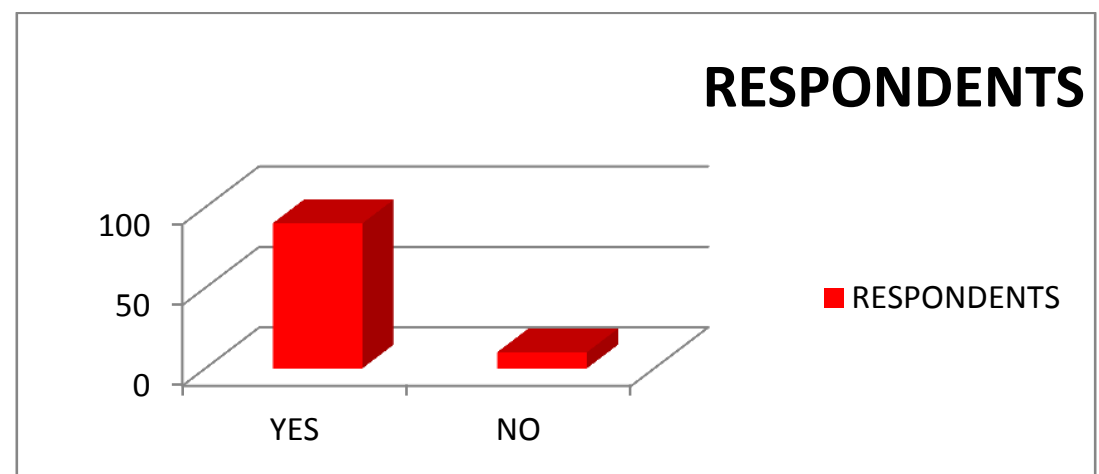

Interpretation: A look at the chart shows that $90 \%$ of the members are suggesting and $10 \%$ of the members are not suggesting.

6) What is your opinion about mileage?

\begin{tabular}{|c|c|c|c|}
\hline S NO & OPINION & RESPONDENTS & $\%$ \\
\hline 1 & EXCELLENT & 50 & 50 \\
\hline 2 & GOOD & 30 & 30 \\
\hline 3 & AVERAGE & 15 & 15 \\
\hline 4 & POOR & 5 & 5 \\
\hline
\end{tabular}

CHART

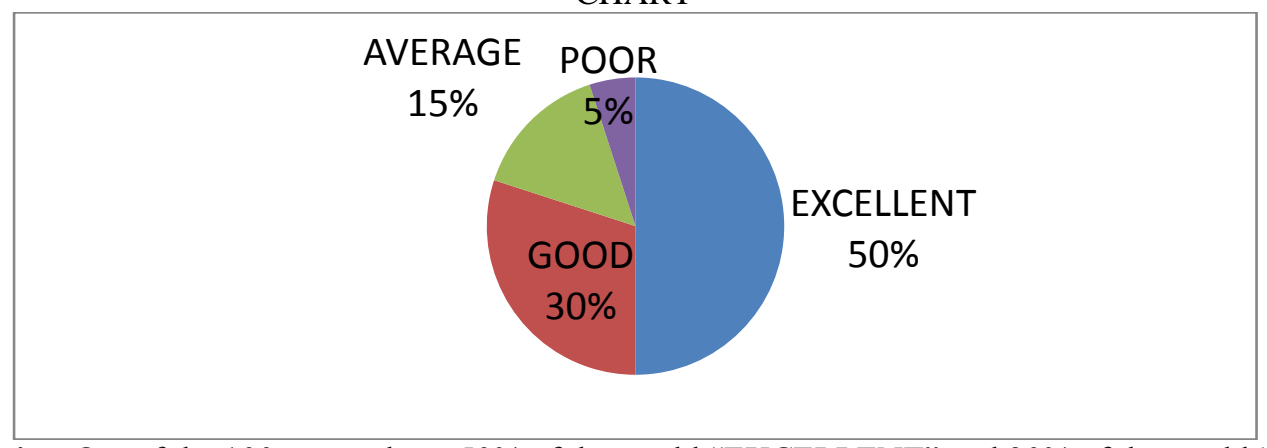

Interpretation:Out of the 100 respondents $50 \%$ of them told "EXCELLENT" and 30\% of them told "GOOD" and $15 \%$ of them told "AVERAGE" and $5 \%$ of them told "POOR". 
7)Since how many months have you been using Honda Bike?

\begin{tabular}{|l|c|c|}
\hline & NO. OF RESPONDENTS & PERCENTAGE \\
\hline 0-6 MONTHS & 23 & $23 \%$ \\
\hline 6-12 MONTHS & 37 & $37 \%$ \\
\hline 1-2 YEARS & 36 & $36 \%$ \\
\hline MORE THAN 2 YEARS & 04 & $04 \%$ \\
\hline TOTAL & $\mathbf{1 0 0}$ & $\mathbf{1 0 0 \%}$ \\
\hline
\end{tabular}

Using of the service (in months):

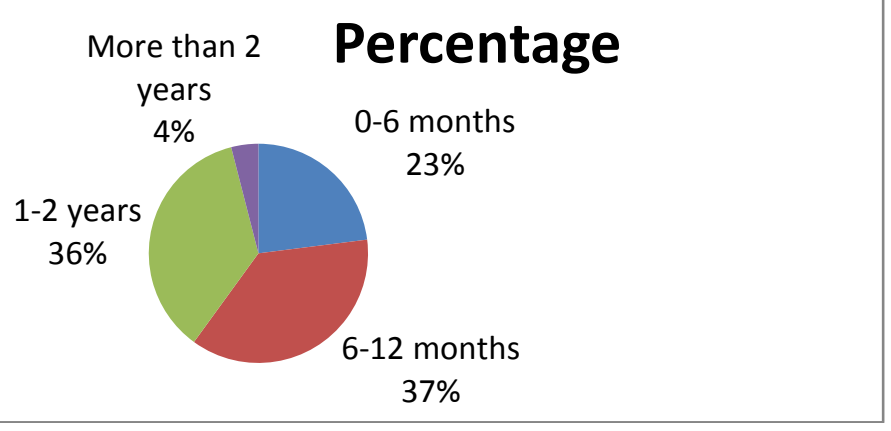

Interpretation:From the above table it is seen that $37 \%$ of the respondents have been using Honda products for past one year. While $36 \%$ have been using it for more than 1 year,and a significant $23 \%$ of respondents have been using the service for less than six months.Only $4 \%$ of the respondents have been using Honda products for more than 2 -years.

8) What is the reason for choosing this Bike?

\begin{tabular}{|l|c|c|}
\hline & NO. OF RESPONDENTS & PERCENTAGE \\
\hline LESS PRICE & 20 & $20 \%$ \\
\hline QUALITY SERVICE & 56 & $56 \%$ \\
\hline BRAND IMAGE & 24 & $24 \%$ \\
\hline TOTAL & 100 & $100 \%$ \\
\hline
\end{tabular}

Reason for choosing the service:

\section{No. of respondents}

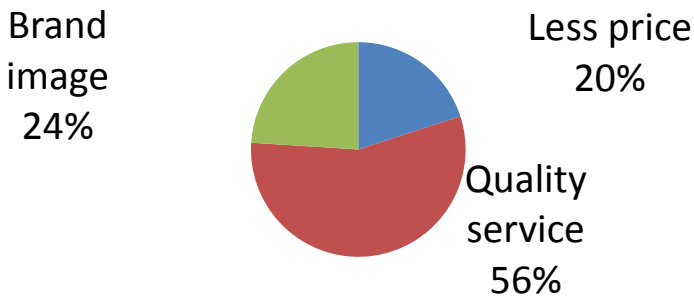

Interpretation:From the above table it is shown that $56 \%$ of the respondents are citing quality of service as the factor. While $24 \%$ cited brand image as the reason for choosing the service. As far as price is concerned only $20 \%$ of the respondents have quoted it as the reason for choosing this service.

9) Why do you prefer for this service?

\begin{tabular}{|l|c|c|}
\hline & NO. OF RESPONDENTS & PERCENTAGE \\
\hline CONVENIENCE & 53 & $53 \%$ \\
\hline ECONOMICAL & 30 & $30 \%$ \\
\hline SECURITY & 04 & $04 \%$ \\
\hline FEATURES & 13 & $13 \%$ \\
\hline TOTAL & $\mathbf{1 0 0}$ & $\mathbf{1 0 0 \%}$ \\
\hline
\end{tabular}


Preferring for this service:

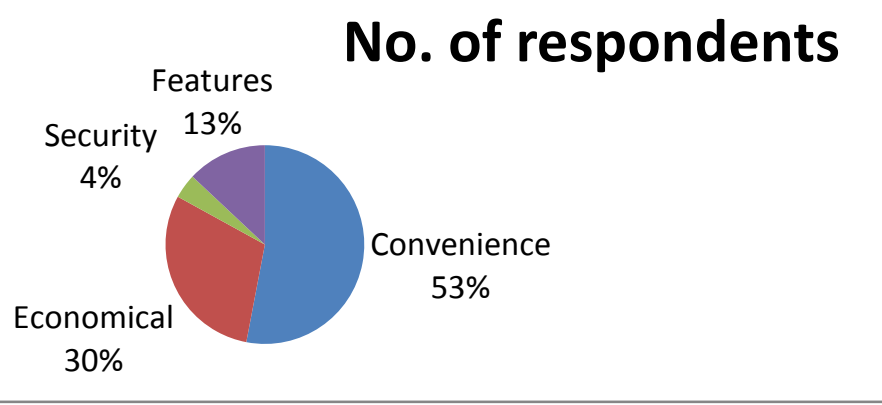

Interpretation:In today's busy world convenience seems to be the most overriding factor while preferring a cellular service. It is clear that $53 \%$ of the respondents have preferred this service due to easy \& hands free availability, making it convenient to use it. On the other hand $30 \%$ have said economy of the service, while $13 \%$ of the respondents have given features as their choice. While a meagre $4 \%$ of the said security as the reason for preferring the service.

10)Do you feel that the instruments being provided along with the services is ok or you want a change (as per choice)?

\begin{tabular}{|l|c|c|}
\hline & NO. OF RESPONDENTS & PERCENTAGE \\
\hline YES, WE WANT CHANGE & 10 & $10 \%$ \\
\hline NO, IT IS OK & 90 & $90 \%$ \\
\hline TOTAL & $\mathbf{1 0 0}$ & $\mathbf{1 0 0 \%}$ \\
\hline
\end{tabular}

Instruments provided with service are ok or not:

\section{Chart Title}

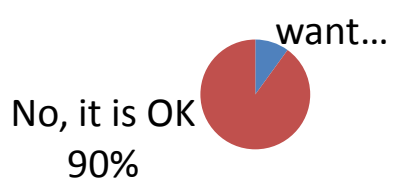

Interpretation:From the above table it is clear that $90 \%$ of the total 100 respondents don't want any change in the instruments being provided by the company, they want as it is. But the remaining $10 \%$ of the respondents are willing to have change in that at some choice, in terms of certain features as compared with the competitors.

11)Are you satisfied with the quality of service being provided?

\begin{tabular}{|l|c|c|}
\hline & NO. OF RESPONDENTS & PERCENTAGE \\
\hline YES & 85 & $85 \%$ \\
\hline NO & 5 & $5 \%$ \\
\hline TO SOME EXTENT & 0 & $0 \%$ \\
\hline CAN'T SAY & 10 & $10 \%$ \\
\hline TOTAL & $\mathbf{1 0 0}$ & $\mathbf{1 0 0 \%}$ \\
\hline
\end{tabular}

Satisfaction I with the quality of service:

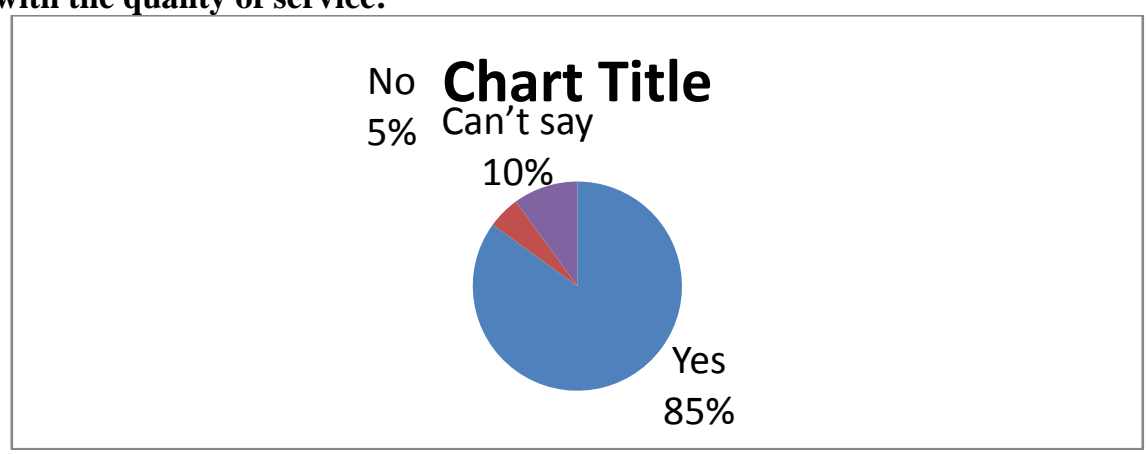


Interpretation:From the above table it is clear that $85 \%$ of the respondents are satisfied with the quality of service while a significant number i.e., $10 \%$ of the respondents couldn't say anything and $5 \%$ of the respondents replied they are not satisfied with the quality of service.

\section{2) Satisfaction with the Honda Bikes pickup}

\begin{tabular}{|c|c|c|c|}
\hline S.NO & OPTIONS & RESPONDENTS & PERCENTAGES \\
\hline 1 & EXCELLENT & 36 & $36 \%$ \\
\hline 2 & GOOD & 17 & $17 \%$ \\
\hline 3 & AVERAGE & 20 & $20 \%$ \\
\hline 4 & POOR & 27 & $27 \%$ \\
\hline & & $\mathbf{1 0 0}$ & $\mathbf{1 0 0}$ \\
\hline
\end{tabular}

\begin{tabular}{|c|c|}
\hline POOR & \\
& EXCELLENT \\
& \\
& $36 \%$ \\
& \\
AVERAGE & GOOD \\
$20 \%$ & $17 \%$ \\
\hline
\end{tabular}

Interpretation:From the above table it is clear that $53 \%$ of the respondents are satisfied with the Pickup of bike while a significant number i.e., $20 \%$ of the respondents couldn't say anything and $27 \%$ of the respondents replied they are not satisfied with the pickup of bike.

13) What do you think promotion of HondaProducts should be done?

\begin{tabular}{|l|l|l|l|l|l|}
\hline Offers & Advertisement \& offers & Advertisement & Free Service & Free Service\& offers & $\begin{array}{l}\text { All the } \\
\text { above }\end{array}$ \\
\hline 8 & 10 & 17 & 42 & 5 & 6 \\
\hline
\end{tabular}

what do you think promotions
should be done
$12 \%$
$5 \% 6 \% 8 \%$
$42 \%$

Interpretation:By this pie-chart we know that the promotions should be done by free service and advertisement.

14)Is the appointment system useful to you?

\begin{tabular}{|l|l|c|}
\hline SL.NO & OPTIONS & RESPONSE \\
\hline 1 & Completely & 25 \\
\hline 2 & Useful & 73 \\
\hline 3 & Not useful & 2 \\
\hline
\end{tabular}

Source: customer survey (primary data) 


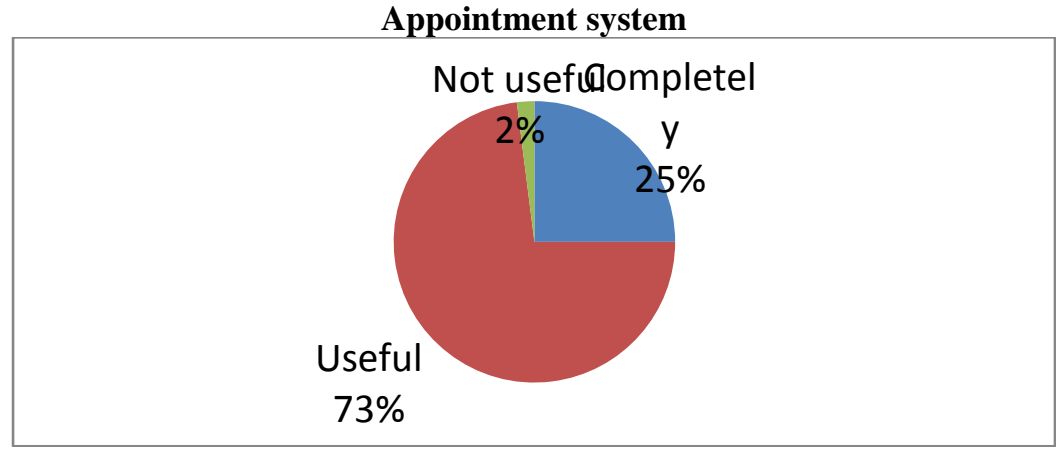

Interpretation:Among the 100 customers when a question was raised regarding the usefulness of service appointment system $25 \%$ of the respondent said completely useful, $73 \%$ said useful and $2 \%$ said not useful.

\section{CHI-SQUARE TEST}

Chi-square $=\sum(\mathrm{O}-\mathrm{E})^{2} / \mathrm{E}$

Null hypothesis: There is no significant difference in the preferable factors.

\begin{tabular}{|c|c|c|c|c|c|c|}
\hline S.NO & TYPE & RESPONDENTS(0) & E & O-E & $(\mathbf{O - E})^{\wedge} \mathbf{2}$ & $(\mathbf{O}-\mathbf{E})^{\wedge} \mathbf{2} / \mathbf{E}$ \\
\hline 1 & MILEAGE & 36 & 25 & 11 & 121 & 4.84 \\
\hline 2 & PICK-UP & 28 & 25 & 3 & 9 & 0.36 \\
\hline 3 & PRICE & 24 & 25 & 1 & 1 & 0.04 \\
\hline 4 & DESIGN & 12 & 25 & 13 & 169 & 6.76 \\
\hline & & & & TOTAL & 12.00 \\
\hline
\end{tabular}

Degrees Of Freedom $=(4-1)=3$

Level of significance $=5 \%$

\section{Chi-square $=\mathbf{1 2 . 0 0}$}

The calculated value is 12.00

The chi-square table value at 5\% level of significance at 3 degrees of freedom is 7.815

Interpretation:The computed value of chi-square is greater than the table valuehence, the null hypothesis is rejected. So, there is significance difference between the preferable factors

\section{Findings}

1. All the respondents were aware about this company.

2. $60 \%$ of customers to know the advertisement of HondaBikes through media, $12 \%$ of customers were through friends and $28 \%$ of customers are through dealers.

3. 90 percent of the customers were completely satisfied with the mileage and performance of the bike, 10 percent of the customers are dissatisfied with the mileage.

4. $73 \%$ of respondents aresatisfied with pick-up of the Honda Bikes and $27 \%$ of the customers are dissatisfied.

5. $56 \%$ of the respondents are attract the quality of the service to choose this bike, $20 \%$ of the respondents are like less price and $24 \%$ of the respondents were like brand image.

6. $50 \%$ of the respondents aresatisfied with the design of the bike, $40 \%$ of the respondents said that average and $10 \%$ of the respondents feel that design is poor.

7. $54 \%$ of the respondents considered the price of the Honda Bikes, as higher where as only $8 \%$ considered as economical and $38 \%$ of the respondent said it as reasonable.

8. $60 \%$ of the respondents felt the explanation to be "excellent". And 35\% of them "very good" and rest of $5 \%$ felt to be "poor". According to them sales executives.

9. According to the chi-square test find that there is significance difference between the preferable factors like mileage,pickup,price and design.

\section{Suggestions}

1. The most important media for consumer durables is television. So, they should go for television advertisements rather going for newspaper, the television advertisements influences more on the people. They should spend some expenditure for T.V. advertisements. 
2. Being the price of the Hondais high they should try to reduce prices because there are many other competitors which can be selling at lower cost. If not, the sales may decrease.

3. More features should be added to the bikes according to the needs of the customer, because their competitors are coming with new models. According to the competitors these people should change the models or change the technology.

4. Company should give some incentives to the dealers for promoting the products of Honda. They should not neglect dealers. They should select good dealers, which they can give customer satisfaction.

5. Company should setup service centres at dealer level itself. They should train some personnel for exclusive maintenance of these two wheelers. They should provide home service to the customers. The personnel should be appointed by company to the dealers. The service should be accurate.

\section{Conclusion}

A study was useful in understanding the customer relationship management of Honda Bikes among a various customers launching new formulations can make Honda to the pioneer in many market segments. Honda was inferred that most customers of high-income group preferred the supply of Honda Bikes. About 70\% of customers are aware of Honda Bikes. Most of the customers agree that Honda is best quality with reasonable price the attitude $50 \%$ of customers towards price of Honda Bikes is reasonable. But $10 \%$ of the customers are asking for improvement in the quality.

[1]. Philip Kotler 2000/e- Marketing Management

\section{References}

[2]. G.C. Beri- Marketing Research

[3]. Aaker Myers "Advertising Management" prentice Hall of India pvt. Ltd, New Delhi.

[4]. Kothari. C.R,(1998).”Research Methodology”, H.S. Poplai for WishwaPrakashan, New Delhi.

[5]. Philip Kotler., Grey Amstrong.,(1999) "Principles of Marketing", AshokeK.Ghose., New Delhi.

[6]. PhilipKotler.,(1999) "Marketing Management” AshokeK.Ghosh., New Delhi.

[7]. R.S.N. Pillai\&Bagavathi., (1999)"Marketing Management” S. chand\& Co. Ltd,

[8]. Rajan Nair.,(1997) "Marketing" Sultan chands\& sons, New Delhi,

[9]. S.A.Sherlekar,'Modern Marketing”Himalaya publishing House, Bombay.

[10]. Dr.C.Annandan\&M.Prasanna Mohan Raj \&Mr.S.Madhu, A Study on Brand preference of washing soaps in rural areas, Indian Journal of marketing,March2007, Page no-30

[11]. Dr.N.Chandrasekaran, Consumer Behaviour and Brand Preference towards Onida Television -An Empirical Study with Reference to Karur, Tamilnadu,Indian Journal of Marketing, July 2009,Page No-58

[12]. Dr.S.K.Sinha\&Ajay Wagh, Analysing growth of cellular telecom sector and understanding consumer's preferences and choices on the use of cell phone-Indian Journal of Marketing. Sep 2008 Page no -2

[13]. RachelDardis, HoracioSoberon-Ferrer, consumer's preferences for Japanese auto mobiles,Journal of consumer affairs, summer 1994

[14]. www.hero.com

[15]. www.pioneerherohonda.com

[16]. www.autoindia.com

[17]. http://www.thehindubusinessline.com/companies/india-to-be-hondas-largest-2wheeler-market/article2777985.ece 